\title{
Managing Migrant Contestation
}

Land appropriation, intermediate agency, and regulated space in Shenzhen

\section{Edmund W. Cheng}

\section{(2) OpenEdition \\ Journals}

Electronic version

URL: http://journals.openedition.org/chinaperspectives/6432

DOI: 10.4000/chinaperspectives.6432

ISSN: 1996-4617

\section{Publisher}

Centre d'étude français sur la Chine contemporaine

\section{Printed version}

Date of publication: 1 June 2014

Number of pages: $27-35$

ISSN: 2070-3449

\section{Electronic reference}

Edmund W. Cheng, « Managing Migrant Contestation », China Perspectives [Online], 2014/2 | 2014,

Online since 01 January 2017, connection on 28 October 2019. URL : http://journals.openedition.org/ chinaperspectives/6432; DOI : 10.4000/chinaperspectives.6432 


\title{
Managing Migrant Contestation
}

\author{
Land appropriation, intermediate agency, and regulated space in Shenzhen
}

\author{
EDMUND W. CHENG
}

\begin{abstract}
This study considers the conditions under which China's massive internal migration and urbanisation have resulted in relatively governed, less contentious, and yet fragile migrant enclaves. Shenzhen, the hub for rural-urban migration and a pioneer of market reform, is chosen to illustrate the dynamics of spatial contestation in China's sunbelt. This paper first correlates the socialist land appropriation mechanisms to the making of the factory dormitory and urban village as dominant forms of migrant accommodation. It then explains how and why overt contention has been managed by certain intermediate agencies in the urban villages that have not only provided public goods but also regulated social order. It ends with an evaluation of the fragility of urban villages, which tend to facilitate urban redevelopment at the expense of migrants' living space. The interplay between socialist institutions and market forces has thus ensured that migrant enclaves are regulated and integrated into the formal city.
\end{abstract}

KEYWORDS: China, land rights, local politics, migrant enclaves, public goods, urban contestation.

\section{Introduction}

C hina's post-socialist urban transformation is unprecedented. In 1978, China had 158 cities, an urbanisation level of $17.9 \%$, and a total of 172 million people living in urban areas. By 2012, these figures had risen to $658,52.6 \%$, and 712 million respectively. Within 35 years, China's urbanisation surpassed the $50 \%$ benchmark, indicating the addition of around 540 million people to its urban population. (1) In 2012, the total number of the floating population reached 236 million, meaning that rural migrants who did not have an urban household registration (hukou) were the primary source of the urban population increase.

Millions of rural migrants who were granted geographic mobility for travel and work but denied socioeconomic entitlements provided by work units (danwei), compounds, and subsidised housing in host cities, were forced to seek accommodations on their own. (2) This severe transformation created migrant enclaves known as chengzhongcun (城中村), literally villages amidst the city or urban villages, within booming Chinese cities.

$\mathrm{Ma}$ and Xiang first identified peasant enclaves as a "new urban mosaic that did not exist in Maoist China" and correlated their formation with the resurgence of kinship and its social networks. ${ }^{(3)}$ Subsequent studies have recognised the function of urban villages in enabling rural migrants to reside, work, and survive in cities during a period of rapid urban transformation. ${ }^{(4)}$ However, urban studies have tended to emphasise how urban villages encounter planning regimes in negotiating property rights, effective land use, and spatial regularity. ${ }^{(5)}$ Sociological analyses have aimed to examine the changes in social exclusion, income inequality, and the urban fringe along the global chain of production, ${ }^{(6)}$ and anthropological accounts have attempted to reveal the communal networks and power relations in specific enclaves or among particular migrant groups. (7) $^{(7)}$

Building on this body of literature, the historical institutional perspective featured here aims to explain the dynamics by which China has managed and regulated the spatial contestation of rural migrants. This approach embodies a historical orientation to study changes and attends to the ways in which institutions contingently shape behaviours. It applies process tracing to reveal the interplay between socialist land system and grassroots agency in the making of governed migrant enclaves. The hukou system, another socialist institution, is well documented as a source of social control and spatial regularity in China's cities. ${ }^{(8)}$ While this paper uses the arrangements in the factory dormitory to illustrate a similar pattern of spatial division, it mainly concerns the role of intermediate agencies in regulating urban villages. The regulated space is considered a product of embeddedness and uncertainty, in which the influences of socialist institutions are as important as market forces.

This paper begins by examining how the factory dormitory and urban village have become the major forms of migrant accommodation in Shenzhen. It discusses how a socialist legacy has reproduced factory dormitories, thereby creating a buffer zone to host and regulate new migrants who were

1. UN-habitat, State of Chinese Cities 2010/2011, New York, Earthscan, 2010, p. 131; National Bureau of Statistics (NBS), China Statistical Yearbook 2012, Beijing, China Statistics Press, 2012.

2. National Health and Family Planning Commission (NHFPC), Report on China's Migrant Population Development, Beijing, China Population Press, 2013, p. 1.

3. Laurence J.C. Ma and Biao Xiang, "Native Place, Migration and the Emergence of Peasant Enclaves in Beijing," The China Quarterly, Vol. 155, 1998, p. 546.

4. John Friedmann, China's Urban Transition, Minneapolis, University of Minnesota Press, 2005, pp. 70-74; Yan Song, Yves Zenou, and Chengri Ding, "Let's Not Throw the Baby out with the Bath Water: The Role of Urban Villages in Housing Rural Migrants in China," Urban Studies, Vol. 45, No. 2, 2008, pp. 313-330.

5. George C. S. Lin, Developing China: Land, Politics and Social Conditions, London, Routledge, 2009; Wu Fulong, Zhang Fangzhu, and Chris Webster, "Informality and the Development and Demolition of Urban Villages in the Chinese Peri-Urban Area," Urban Studies, Vol. 50, No. 10, 2013, pp. 1919 1935;

6. John R. Logan, "Urban China in Comparative Perspective," in John R. Logan (ed) Urban China in Transition, Oxford, Blackwell, 2008, pp. 1-24; Dorothy Solinger, Contesting Citizenship in Urban China: Peasant Migrants, the State and the Logic of the Market, Berkeley, University of California Press, 1999, pp. 248-62.

7. Biao Xiang, Transcending Boundaries: Zheijangcun: The Story of a Migrant Village in Beijing, Leiden, Brill, 2005; Li Zhang, Strangers in the City: Reconfigurations of Space, Power, and Social Networks within China's Floating Population, Stanford, Stanford University Press, 2001.

8. Tiejun Cheng and Mark Selden, "The Origins and Social Consequences of China's Hukou System," The China Quarterly, Vol. 139, 1994, pp. 644-668; Feiling Wang, Organising Through Division and Exclusion: China's Hukou System, Stanford, Stanford University Press, 2005. 


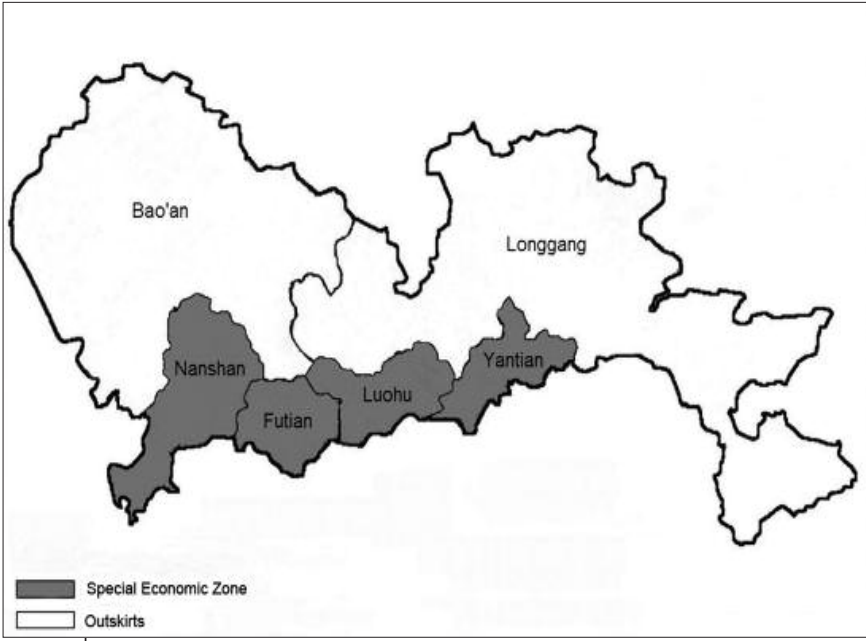

Map 1 - Administrative divisions of Shenzhen, 1978-2010 (c) Edmund W. Cheng

often financially unprepared for residing in the city. It also explains how the collective land ownership system has created affordable housing in urban villages to accommodate migrant entrepreneurs and workers. It then reveals the role of joint-stock companies in migrant enclaves. Serving as local bosses, these companies provided public goods, regulated social order, and aligned with municipal authorities. These intermediate agencies not only prevented China's urban villages from developing into slums and the urban decay and social disorder associated with them, but also reduced the number of recognised stakeholders and reduced organised resistance during urban redevelopment.

Despite the absence of open contention, one should not overlook the dynamics introduced by rural migrants' continuous inhabitation and daily exchanges in cities. Nor should this be interpreted as the migrants' approval or acceptance of the social and spatial settings. However, this paper mainly concerns how and why socialist institutions and market forces work together to regulate these migrant enclaves. We argue that because of the mediation by these intermediate agencies between the state and grassroots society, China's migrant enclaves demonstrate unique patterns and characteristics compared with those in other developing countries, but also share similarities with the rest of the urban population and the formal city. ${ }^{(9)}$

\section{Sites and methods}

Shenzhen is a hub for rural-urban migration and the pioneer of market reforms. Between 1979 and 2012, Shenzhen maintained an average annual GDP growth rate of $24.8 \%$ and emerged from a county of 314,000 people to become a metropolis with a permanent population (changzhu renkou) of more than 10 million, of which three quarters were floating population (liudong renkou), i.e., mainly rural migrants. ${ }^{(10)}$ We therefore chose it as a case study to exhibit the typical spatial contestations in China's sunbelt.

Until 2010, Shenzhen maintained a dual administrative structure that divided the municipality into two divisions. One administration governed the districts of Luohu, Futian, Nanshan, Yantian, and several early industrial zones designated as the city centre (guannei 关内). The territorial jurisdiction of the Special Economic Zone (SEZ) was restricted to this $395 \mathrm{~km}^{2}$ of land and included 91 administrative villages. The other administration governed the districts of Bao'an and Longgang and the new high-tech zones in the sub- urbs. This area included 239 administrative villages spread across $1,553 \mathrm{~km}^{2}$ of land at the outskirts (guanwai 关外). (11) Map 1 illustrates the boundary of the administrative divisions. Nearly all of the factory dormitories were located in the spacious outskirts, whereas urban villages were found in both divisions.

Our fieldwork was conducted between March 2012 and September 2013, involving interviews, participant observation, and documentary research. The findings were primarily drawn from observations made in two urban villages in the city centre, with one urban village on the outskirts serving as a control. These villages were selected to depict a representative trajectory of spatial contestations in China's sunbelt. Each of the villages has been governed by a joint-stock company that was privatised from a village collective. All of them have transformed into heterogeneous communities over the course of rural-urban migration and urban sprawl, illustrating dynamic contestations between the native villagers and different groups of rural migrants. They are also large villages of comparable size whose demands for public goods are immediate and huge. The primary differences between them are that the two villages in the city centre are much wealthier than the village in the outskirts, and that they are located in three different districts. This controlled study allows us to assess the influences of demographic, economic, and institutional factors.

These sites were also chosen because of personal connections with the inhabitants. Through our initial contacts, we were introduced to several local bosses, clan leaders, and migrant workers who extended our reach in the urban villages. This paper draws on 23 semi-structured interviews with the heads or deputies of joint-stock companies, city planning officials, company executives, NGOs staff, and native villagers. Numerous conversations were also conducted with rural migrants who are shopkeepers, security guards, or ordinary tenants. These informal contacts enriched our ethnographic accounts and served to verify the data collected by other means.

\section{Migrant accommodation in contested space}

Shenzhen's spatial contestation has been accelerated by extensive ruralurban migration and continuous fiscal decentralisation. Shenzhen has experienced two phases of rural-urban migration, corresponding to different contestation dynamics. The municipality maintained an average urban population growth rate of $15.8 \%$ in the 1980 s, and that rose to $24 \%$ in the first half of the 1990s. ${ }^{(12)}$ In the first period, it primarily absorbed intra-provincial migrants, including some rusticated youth holding an urban hukou. In the second period, it led other cities in experiencing massive inter-provincial migration. (13) Intra-provincial migrants have found it easier to reside with friends or relatives and less costly to return to the countryside once the urban job market becomes saturated or unstable. In contrast, inter-provincial migrants have had a genuine need to find self-help accommodation in host cities.

9. David Bray, Social Space and Governance in China: The Danwei System from Origins to Reform, Stanford, Stanford University Press, 2005, pp. 157-193.

10. Shenzhen Bureau of Statistics (SBS), Shenzhen Statistics Yearbook 2012, Beijing, China Statistics Press, 2012, tables 1-3 and 3-1.

11. SBS, Shenzhen Statistics Yearbook 2012, op cit., table 1-2; Shenzhen Urban Village Redevelopment Office (SUVRO), Shenzhen shi chengzhongcun gaizao gongzuo baogao 2005 (Shenzhen Urban Village Redevelopment Annual Report 2005), p. 2.

12. Ibid.

13. Southern Metropolis Daily, Zhongguo nongmingong sanshinian qianxishi (Thirty Years of Migration History of China's Rural Migrants), Guangzhou, Huacheng Publisher, 2012, pp. 107-108; SBS, Shenzhen Statistics Yearbook 2012, op cit., table 3-1. 


\begin{tabular}{|l|c|c|c|c|c|c|c|c|c|c|c|c|c|}
\hline \multicolumn{1}{|c|}{ Accommodation/Year } & 2001 & 2002 & 2003 & 2004 & 2005 & 2006 & 2007 & 2008 & 2009 & 2010 & 2011 & 2012 \\
\hline Dormitory & 44.8 & 47.8 & 43.8 & 39.1 & 37.7 & 34.0 & 32.9 & 33.6 & 27.8 & 29.8 & 27.2 & 24.4 \\
\hline Construction site & 10.8 & 8.8 & 6.7 & 6.1 & 5.7 & 4.9 & 4.8 & 4.6 & 3.5 & 3.5 & 3.3 & 2.6 \\
\hline Rental house & 30.9 & 34.8 & 42.1 & 45.3 & 47.3 & 52.0 & 52.8 & 52.2 & 58.4 & 57.1 & 59.5 & 63.2 \\
\hline Hotel or hostel & 5.9 & 2.6 & 1.7 & 1.5 & 1.8 & 1.9 & 1.7 & 1.7 & 1.5 & 1.3 & 1.4 & 0.9 \\
\hline Local resident's house & 3.5 & 3.3 & 3.3 & 3.9 & 4.0 & 3.3 & 3.4 & 3.6 & 4.1 & 3.8 & 4.0 & 4.0 \\
\hline Others incl. own apartment & 4.2 & 2.7 & 3.2 & 3.9 & 3.4 & 4.0 & 4.4 & 4.3 & 4.7 & 4.5 & 4.6 & 4.9 \\
\hline
\end{tabular}

Source: Compiled using data from Ministry of Public Security, Collection of Statistical Materials on Temporary Population in China, Beijing, Qunzhong Press, $2001-2012$.

Many first-generation migrants did not build homes in the cities due to their communal ties and ultimate goals: working away for them was primarily a means to improve their families' living standard and status in their native villages. Cheap and substandard housing thus allowed these rural migrants to minimise their living costs in cities and maximise their remittance to their rural families and permanent residences. However, the second-generation migrants have higher individualistic expectations and have adapted to modern lifestyles that can only be fulfilled in the cities. Survey data showed that nearly $80 \%$ of young migrants intend to reside in big cities permanently, developing their careers and raising their families. This behavioural change has created enormous pressures in terms of housing, medical care, child education, and communal services in the cities. ${ }^{(14)}$

The fiscal reform in 1994 further intensified the spatial contestation. The reform replaced the revenue-sharing system with a tax-sharing system under which customs, sales, and the majority of value-added taxes were exclusively central, while taxes on business, stamps, property, and land use were exclusively local. This reform has improved the central government's extractive capacity in relation to the local governments. Booming cities such as Shenzhen were motivated to explore locally generated revenue to maintain public investments and cover social security expenses. It is estimated that land-related revenue accounted for $72 \%$ of the total revenue of Guangdong Province after 1995. ${ }^{(15)}$

This backdrop implies that Shenzhen's urban contestation is probably one of the most severe in the country. When rapid urbanisation and rural-urban migration encounter a fiscally weak and administratively shrunken state, social decay and ungoverned enclaves tend to result. ${ }^{(16)}$ Yet the pattern and nature of Shenzhen's migrant accommodations illustrate certain deviations.

Table 1 shows the types and features of migrant accommodation in Guangdong Province over the last decade. ${ }^{(17)}$ The overall pattern for migrants' choice of accommodation clustered consistently around affordable and temporary housing. The major types of migrant accommodation were dormitory and rental housing, which on average accounted for $84 \%$ of accommodations. Rental housing gradually replaced dormitories as the most favoured migrant accommodation. In Shenzhen, manufacturing workers employed in large enterprises often lived in the dormitories provided by their employers, all of which were adjacent to the factories. Construction workers and domestic workers were respectively accommodated in temporary compounds built onsite and in their employers' private households, both of which were functionally another form of dormitory. Other rural migrants who owned or worked in small and medium enterprises or service industries tended to seek private accommodations on their own. According to an an- nual report from Shenzhen's Urban Villages Redevelopment Office, urban village housing accounted for around $92 \%$ of the rental housing for rural migrants. ${ }^{(18)}$

The majority of migrant accommodations were temporary housing. Over the last decade, less than $5 \%$ of rural migrants purchased houses in cities. Renting urban village apartments or residing in factory dormitories required less capital and provided more flexibility, a rational choice given the migrants' low income-earning capacity in the cities and back-and-forth migration pattern. The fact that the hukou system denies rural migrants socioeconomic entitlements such as subsidised public housing and the ability to obtain a mortgage within their host cities was the institutional factor that forced the migrants to remain perpetually floating.

However, even if rural migrants - as second-class citizens and transients - had a genuine interest in looking for affordable housing or were trapped in temporary housing, these two factors do not explain how and why valuable land under urban sprawl was used to construct dormitories and apartments for the most disadvantaged.

\section{Factory dormitories and the reproduction of controlled space}

Although the quantity of migrant settlements varies between Shenzhen's administrative zones, these zones were constituted under the same collective land system. This is because although the Chinese state nominally owns all of the land, the municipal governments in urban areas and the village collectives in rural areas control the leasing, transfer, and appropriation of land within their jurisdictions. A series of negotiations between two groups of "socialist land masters" who were entitled to various land use rights have thus overshadowed Shenzhen's spatial contestations. ${ }^{(19)}$

The first group was the extension of the broad functional system (xitong 系统) of the Chinese government. Each of the ministries or commissions in

14. NHFPC, Report on China's Migrant Population Development, op cit., 2012, pp. 127-133.

15. Hyun-bang Shin, "Residential Redevelopment and Entrepreneurial Local State: The Implications of Beijing's Shifting Emphasis on Urban Redevelopment Policies," Urban Studies, Vol. 46, No. 13, 2009, pp. 2815-2839; Samuel P.S. Ho and George C. S. Lin, "Emerging Land Markets in Rural and Urban China: Policies and Practices," The China Quarterly, Vol. 175, 2003, p. 700.

16. Mike Davis, Planet of Slums, London, Verso Press, 2006; UN-Habitat, The Challenge of Slums: Global Report on Human Settlements, New York, Earthscan, 2003.

17. Shenzhen does not have such consecutive data, but its selective records concur with Guangdong's.

18. SUVRO, Shenzhen Urban Village Redevelopment Annual Report 2005, op cit. p. 12

19. You-tien Hsing, "Socialist Land Masters: The Territorial Politics of Accumulation," in Aihwa Ong and Li Zhang (eds), Privatizing China: Socialism from Afar, Ithaca, Cornell University Press, 2008, pp. 57-70. 
the State Council and bureaus of the Communist Party has hierarchical units at each territorial level of government. These units include government agencies and state-owned enterprises, which are assigned specific ranks and jurisdictions. Power is therefore fragmented between different xitongs and municipal governments, creating tension but also collaboration on issues of vital interest such as the competition for urban land. There were hundreds of xitongs in Shenzhen, and a few important ones were referred to as the "eight great lords" (bada zhuhou), indicating their capacity and autonomy in the municipality. ${ }^{(20)}$ The xitongs secured a high quantity and quality of land through the provision of loans, leverage, and political support for the municipal government. One retired official commented that the collaborations between different segments of the state promoted growth when Shenzhen was weak and poor, and minimised risks once the municipality became prosperous and autonomous. ${ }^{(21)}$

The primacy of xitong can be traced back to the administrative and spatial arrangements in Shekou, the first open industrial zone created in China's market reforms. China Merchant Group, a subsidiary of the Ministry of Communications, was assigned the responsibility of managing the "window" or testing ground for foreign capital investment in 1979. The transportation xitong has since controlled all of the land appropriation in Shekou, which was approximately one thirtieth of the initial SEZ area. The group formed a management committee in the industrial zone and concurrently expanded its business there. This experiment not only blurred the line between the state and market, but also reproduced certain socialist danwei practices over the course of market reforms. Shekou's founding head and Shenzhen's longest serving mayor concurred that this arrangement aimed to limit the mobility of the workers, contain the effects of the development zone, and safeguard the danwei workers' livelihood during the early reform stages. (22)

Early comers who were worried about the uncertainty of investing in a socialist regime found assurance in these danwei institutions. Two senior executives of manufacturing companies recalled that in addition to the land required to build the factories, their joint enterprises in Shekou were allocated an extra portion of land to build factory dormitories in the early $1980 \mathrm{~s}$ and early 1990s. Apart from the advantage of controlling the factors of production, these manufacturing companies were also attracted by the dividends from the land assets. Although the law prohibits the mortgaging of a factory dormitory, in practice these building structures have always increased the total estimated value of the factory complex. This practice, which is still in force as of 2014 , has provided a strong economic incentive for investors to support the socialist legacy. ${ }^{(23)}$

As a result of the collaboration between the xitongs and firms, many early migrants in Shenzhen's export-oriented industry were not required to find their own urban shelters, as suitable ones were designated in advance. Manufacturing companies have produced many multi-storey factories and highrise dormitories in the industrial zones or outskirts. For large enterprises, the dormitories were built adjacent to the factories; for medium enterprises, the factories and dormitories were packed onto different floors in the same compounds. The most extreme example was Foxconn, a mega world plant that accommodated all of its 550,000 workers in the dormitories on two campuses in Bao'an District. (24)

Although the appearance of a factory dormitory was similar to standard residential apartments, the facilities inside were primitive and the living space was restricted. Our field studies suggest that the migrants slept on bunk beds on which they also hung their clothes and belongings. Each room accommodated eight to 24 people, and hence each individual living space was as small as 20 square feet. The number of inhabitants on each floor ranged from 50 to 120 people, and everyone shared a public bathroom. Regardless of the workers' marital status, they were treated as single and packed into single-sex dormitories. ${ }^{(25)}$ One exception was found on Foxconn's Longhua campus, where all sorts of communal, recreational, and catering facilities were installed. That particular campus was propagated as a model factory for customers, governments, and media. Similar facilities were absent from other Foxconn campuses or other companies. (26)

Several factors were required to reproduce a spatially regulated workplace in the reform era. First, complimentary dormitories were allocated and served as housing stipends to extract marginal labour productivity and control the factors of production, particularly in response to the fluctuation between peak and low seasons. (27) Training, surveillance, and overtime work were more manageable when the migrant workers were accommodated next to the factory. Second, once the migrant workers resided inside a factory complex in an industrial zone, their mobility and interaction with other social actors were effectively restricted. The migrants' service to industrial development was consumed, and their potential threats to city order were minimised.

These practices suggest that the Chinese state might have selectively retreated from its functions during the market reforms. (28) They also inevitably gave rise to the concern that the spatial configurations in China's sunbelt were marginalising the migrants. The migrants were provided with a place to stay and work in the city, but their "rights to the city" were concurrently denied. This thesis proposes that ordinary citizens should have been entitled to participate in important decisions that shaped their city and affected their livelihoods, and that the boundary of public space has since been extended and reproduced by progressive politics. ${ }^{(29)}$ From this perspective, the factory dormitories functioned almost as temporary birdcages in which the rural migrants remained tenants and human resources but not citizens.

Although the migrants' contestations were contained, they were not resolved. Over time, the migrants resorted to various means to sustain their contestations and denote their existence. A small majority chose suicide to voice their grievances, as on the Foxconn campuses. Many of them practised everyday resistance tactics such as nonconformity, footdragging, or seeking advice from third parties. Staff of grassroots NGOs note that migrant workers gradually become aware of their labour rights

20. Chen Wending (ed), Shenzhen Zhexienian: Yizuo bei choumou de xianfeng chengshi (Shenzhen These Years: A Planned Vanguard City), Beijing, China Development Press, 2010, p. 110.

21. Interview, Shenzhen, 13 March 2012.

22. Qiao Tu, Yuan Geng zhuan: gaige xianchang 1978-1984 (Yuan Geng's Biography: Reform on Spot 1978-1984), Beijing, Writer's Publisher, 2008, pp. 345-354; Shenzhen Local Chronicles Office, Li Hao Shenzhen Tequ fangtanlu (Li Hao's Interviews in Shenzhen), Shenzhen, Haitian Publisher, 2010, pp. 52-61.

23. Interviews, Hong Kong, 2 and 12 December 2012.

24. Pun Ngai and Jenny Chan, "Global Capital, the State, and Chinese Workers: The Foxconn Experience," Modern China, Vol. 38, No. 4, 2012, pp. 386, 394-395.

25. Fieldwork, Shenzhen, 12-18 March 2012.

26. Pun Ngai and Jenny Chan, "Global Capital, the State, and Chinese Workers," art. cit., p. 394; Min Zhou and Guoxuan Cai, "Trapped in Neglected Corners of a Booming Metropolis: Residential Patterns and Marginalization of Migrant Workers in Guangzhou," in John R. Logan (ed), Urban China in Transition, Oxford, Blackwell, 2008, pp. 230-233.

27. Ross Perlin, "Chinese Workers Foxconned," Dissent, 2013, pp. 46-52

28. David Bray, Social Space and Governance in China, op. cit., pp. 180-193, which discusses similar social and spatial settings in the making of community (shequ).

29. David Harvey, The Rebel City: From the Right to the City to the Urban Revolution, New York, Verso, 2012; Don Mitchell, The Right to the City: Social Justice and the Fight for Public Space, New York, Guilford Press, 2003. 
and the available mediation channels. ${ }^{(30)}$ Yet their dominant strategy is to exit rather than to voice protest or demands. When a choice is given, migrant workers usually choose to move from factory dormitories to urban villages. Surveys compiled by local NGOs reveals that whereas residing in urban villages may not be migrant workers' first priority after entering the municipality, it is a common second step. Freedom from surveillance is one reason; integration with the urban fabric and lifestyles is another. ${ }^{\left({ }^{31}\right)}$ This in part explains why urban villages have overtaken factory dormitories as the dominant form of migrant settlement in recent years.

\section{Privatised enclaves on collective land}

The joint-stock companies in the urban villages are the second group of socialist land masters. Despite the market reforms, China continued to stipulate a dual land tenure system in which urban land belonged to the state and rural land belonged to the village collectives. Each member of the rural community was entitled to an equal and inalienable piece of land that was tenured and free of charge. The Land Administrative Law (2004) allowed rural land to be acquired for urban development on the condition that appropriate compensation was made. If the requisitioned land belonged to the "land for construction" or "land for farming" classifications, then the authority only had to provide financial compensation. If the requisitioned land belonged to the "land for dwelling" (zhaijidi) classification, the authority had to not only compensate the native villagers, but also nationalise the collective land and hence transfer the villagers' hukou from rural to urban.

Although land for construction and farming was frequently tapped for urban development and renewal, land for dwelling was left untouched until large-scale urban redevelopment projects began in the mid-2000s. This was a result of the complicated and costly requisition mechanisms required for this type of land, and of the risk of openly violating fundamental socialist rights. ${ }^{(32)}$ The entitlement to, transfer, and size of the land for dwelling are regulated by local decrees. In Guangdong Province, the right to transfer land for dwelling is restricted to the respective collective. ${ }^{(33)}$ In the municipality of Shenzhen, the size of the buildings on each piece of land for dwelling was limited to $480 \mathrm{~m}^{2}$. Across China, the distribution of land for dwelling was allocated in terms of households rather than individuals. However, an unmarried native villager under the age of 30 regardless of sex was recognised as a household in Shenzhen. Native villagers were defined as those who registered before 1 January 1991 in the city centre and before 29 October 2004 in the outskirts, i.e., the dates on which the land in the respective areas was nationalised. ${ }^{(34)}$ Because the descendants of native villagers are no longer entitled to the allocation of land for dwelling, the institutional foundation for the formation of urban villages has been removed.

Most of the urban village housing was built on land for dwelling, the category into which rural land fell within the administrative boundaries of each city. This process was the result of rapid urbanisation and industrialisation, whereby cities expanded and absorbed the farmlands and villages of periurban areas into their jurisdictions. In 2000, Shenzhen had 241 urban villages occupying $43.9 \mathrm{~km}^{2}$ and housed 2.15 million inhabitants. By 2005, the figure rose to 320 urban villages, occupying $93.5 \mathrm{~km}^{2}$ and housing 5.02 million inhabitants, of which 4.69 million were rural migrants. ${ }^{(35)}$

In 1992, all of the village committees were privatised into joint-stock companies whose shares were allocated according to native households, and males were overwhelmingly represented. ${ }^{(36)}$ Although a typical urban village in Shenzhen had around 70,000 people, its property rights were confined to around 1,100 shareholders who were native households in Shenzhen's administrative villages. Its administrative power was concentrated in a small group of village bosses. Three out of the four joint-stock company chairmen and deputies we interviewed had held their positions since 1992, and two had been village committee chairmen prior to 1992.

Comparing the characteristics of Shenzhen's urban villages with the squatter settlements in the developing world revealed many differences and only a few similarities. The following sections introduce the similarities and then explain the differences in terms of space, affluence, order, and prospects. Prior to our examination of urban village characteristics, we briefly define the features of a slum. UN-Habitat defines slums as indicators of urban poverty and their proliferation as one of the most pressing global issues. ${ }^{(37)}$ Some refer to slums as a hotbed for organised crime, spatial exclusion, and perpetual marginalisation. ${ }^{(38)}$ Others note that a slum is an enclave where the state has been perpetually replaced by other coercive forces or social networks. ${ }^{(39)}$ Simply put, a typical slum can be defined in terms of urban poverty, social decay, and political anarchy. Once it emerges, a slum becomes a substandard, irregular, and durable enclave.

Urban villages are similar to squatter settlements in that they offer cheap and affordable shelters to poor rural migrants. Because the land for dwelling is free, the cost of a house is almost identical to the cost of construction. The capital investment for such self-built housing is relatively small and can be easily financed through the villagers' personal savings or borrowed from relatives, friends, and local credit unions. Urban villages hence offer highly accessible accommodation at decreased prices, making them extremely competitive in a fluxing city's low-end rental market.

In 2005, the average rent in Shenzhen's urban villages was only one- to two-thirds that of formal settlements. According to real-estate agents and landlords, the rent for urban village housing accounted for roughly onefifth to one-seventh of rural migrants' monthly income. As of 2012, a twobedroom apartment in the outskirts, rented by migrant workers who either refused to live or were not given a place in a factory dormitory, cost between 300 and 600 yuan a month. Similar sized apartments in urban vil-

30. Interviews, Shenzhen, 21 and 22 September 2013.

31. Fieldwork, Shenzhen, 21-30 April 2012. See also Lei Guang, "Guerrilla Workfare: Migrant Renovators, State Power, and Informal Work in Urban China," Politics \& Society, Vol. 33, No. 3, 2005, pp. 481-506; Pun Ngai and Jenny Chan, "Global Capital, the State, and Chinese Workers," art. cit.

32. L. Zhang, Simon X. B. Zhao, and J. P. Tian, "Self-help Housing and Chengzhongcun in China's Urbanization," International Journal of Urban and Regional Research, Vol. 27, No. 4, 2003, pp. 918 920; Li Tian, "The Chengzhongcun Land Market in China: Boon or Bane?" International Journal of Urban and Regional Research, Vol. 32, No. 2, 2008, pp. 290-292.

33. Guangdong Government, Administrative Measures of Guangdong Province for the Circulation of the Right to the Use of Collectively-owned Land for Construction Purposes, Guangdong Decree, 2005, No. 100.

34. Shenzhen Government, Shenzhen Provisional Measures for Construction of Native Villagers' NonCommercial Property, Shenzhen Gazette, 2006, No.106.

35. Yan Song et al., "Let's Not Throw the Baby out with the Bath Water," art. cit., p. 314; SUVRO, Shenzhen Urban Village Redevelopment Annual Report 2005, op. cit., pp. 3-4.

36. Li Tian, "The Chengzhongcun Land Market in China," art. cit., p. 286; SUVRO, Shenzhen Urban Village Redevelopment Annual Report 2006, op. cit., p. 12.

37. UN-Habitat, State of the World's Cities 2008/2009, London, New York, 2009, p. 91; UNHabitat, The Challenge of Slums: Global Report on Human Settlements, Revised and updated edition,New York, Earthscan, 2010, pp. 7-9.

38. Mike Davis, Planet of Slums, op. cit.; Robert Neuwirth, Shadow Cities: A Billion Squatters, A New Urban World, London, Routledge, 2006.

39. Brodwyn Fischer, Bryan McCann and Javier Auyero (eds), Cities from Scratch: Poverty and Informality in Urban Latin America, Durham, Duke University Press, 2014. 


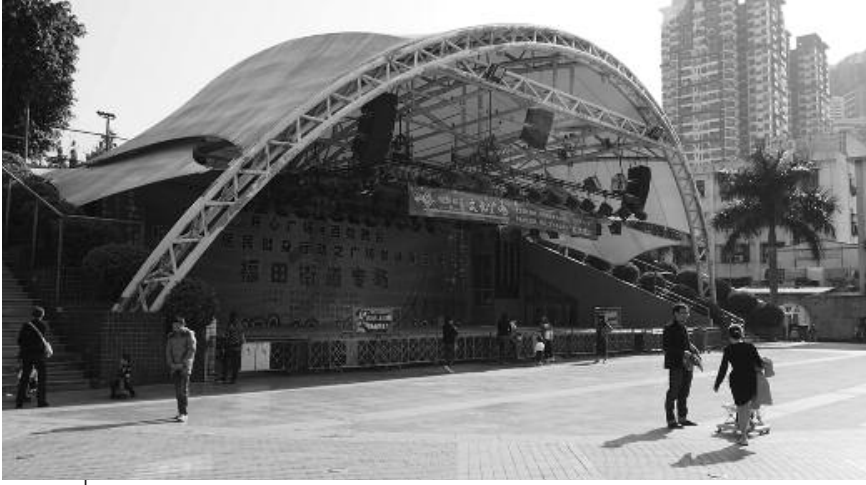

Photo 1 - Recreational and cultural facilities. (c) Edmund W. Cheng

lages in the city proper, which were only affordable to migrant entrepreneurs or white-collar migrants, cost between 800 and 1,500 yuan. ${ }^{(40)}$

Apartments in urban villages are similar in terms of housing standards. They are often crowded and violate fire and building regulations. Subordinated to a rural land system and regulated by rural apparatuses, villagers enjoyed more flexibility in adopting the city planning regulations. An estimated $56 \%$ of the buildings in Shenzhen contained illegal structures, the majority of which were concentrated in the urban villages. ${ }^{(41)}$ Moreover, motivated by high demand and lucrative gain, the villagers commonly built high-density housing that maximised floor area. Houses in the city centre were kept at around five to six storeys high, while those in the outskirts were pushed to 12 storeys after 2000. These exceeded the municipal building regulations that capped the height of village houses at three storeys and $480 \mathrm{~m}^{2}$.

Poverty and substandard living environments have contributed to the spread of illegal activity, which is another defining feature of slums and shantytowns. Prostitution, gambling, and drugs (huangdudu) became prominent in some urban villages, some of which were highlighted by Shenzhen's Public Security Bureau as black spots with frequent and high occurrences of criminal activity. Some landlords and public officials in the urban villages were accused of perpetrating and protecting those crimes. ${ }^{(42)}$ However, none have thrown the enclaves into anarchy by substituting joint-stock companies or excluding municipal intervention.

\section{Wealth and order in urban villages}

Although urban villages resemble shantytowns to the extent that they are indicators of both poverty and deviant activity, they differ greatly in terms of their spatial form and economy. First, although a structure may be illegal, that does not mean the building materials are primitive and unsafe. On the contrary, most of the apartments in Shenzhen's urban villages were built with durable materials by professional construction teams. Each house normally contained a foundation, windows, glazed tiles and roofing, along with shared kitchens and bathrooms. The apartments were often rented to several migrants of the same kin or subleased by an agency working on behalf of the landlords. Second, durable materials were used because the housing was not a one-off purchase commodity, but rather a financial asset that could generate regular dividends. Precedents suggested that although unsafe and hazardous buildings had been torn down, illegal or unauthorised structures qualified for compensation, albeit discounted. Relatively durable buildings would therefore maximise the villagers' claims for appropriate compensation during urban renewal. Third, because the affluent native vil-

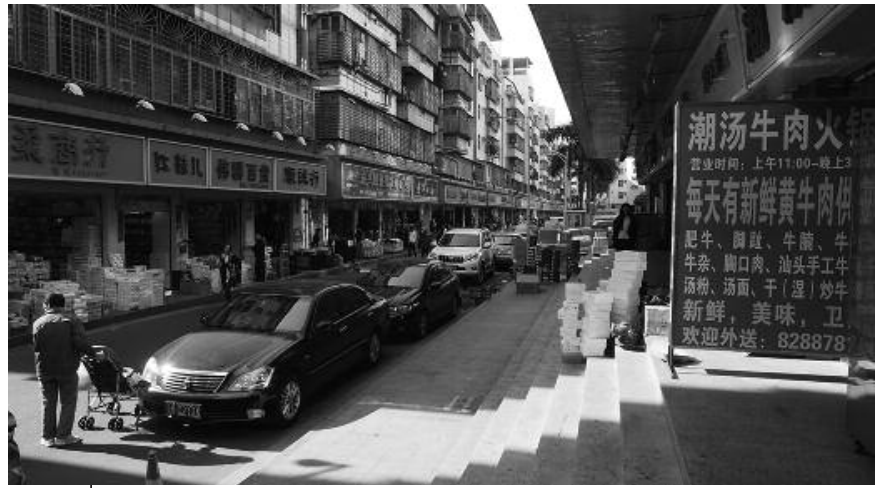

Photo 2 - Commercial street of the Teochow clan. () Edmund W. Cheng

lagers were legally restricted and communally bonded to stay in their apartments, they had an incentive to maintain a higher building standard. (43)

Due to the low income-earning capacity of migrants and their back-andforth migration pattern, landlords had little incentive to decorate apartments. Most apartments were thus rented out unfurnished and without any electrical appliances. However, this does not indicate that every urban village was a source of squalor or despair. In fact, the standard of living varied greatly in different urban villages and among different migrant groups. In most cases, the upper floors of the urban village houses were rented to migrant workers to live in, and migrant entrepreneurs used the ground floors to conduct business. Apart from individual practices and local brands, global chains including Adidas, McDonald's, and Wal-Mart had authorised retailers or opened stores in the urban villages. Another indicator of the relative affluence of urban villages was the common problem of a lack of parking space, caused by the inhabitants' ever-increasing car ownership and corresponding with the wealth of migrant entrepreneurs and white-collar migrants.

Furthermore, the urban village also distinguished itself in terms of public amenities provision. Pathways, parks, parking spaces, street lighting, schools, clinics, electricity/water supply, and public security were preserved or guaranteed. Water, electricity, and regulated parking spaces were private goods made available to those who could afford them. Concrete pathways, parks, street lighting, and public security were non-excludable and non-rival public goods that could be consumed by every inhabitant, including native villagers and rural migrants (Photo 1). Education and medical services were excludable but non-rival club goods allocated to specific sectors of the communities. In general, scholarships were exclusive for native villagers, and clinical services were available to everyone at differentiated rates. Most schools were reserved for the children of native villagers, but the remainder were open to everyone. The Teochew and Hakka clans, who have always been the largest commercial tenants and service providers in the urban villages, have enjoyed priority in the allocation and consumption of these club goods and services (Photo 2). ${ }^{(44)}$

40. Zhong Cheng and Huang Jian-xin, Shenzhenshi nongcun chengshihua lishi yiliu weifa jianzhu yange xianzhuang ji duice yanjiu (Study on the Course, Current Status, and Measure towards Historical Illegal Buildings in Shenzhen's Urbanisation), Beijing, China University of Political Science and Law Press, 2013, pp. 86-89; Interviews, Shenzhen, 17 and 18 August 2012.

41 Ibid., pp.3, 32.

42. Interviews, Shenzhen, 21 and 22 August 2012; Southern Metropolis Daily, 1 August 2013, GA09 and 26 September 2013, SA43.

43. Fieldwork, Shenzhen, 12-18 March 2012.

44. Fieldwork, Shenzhen, 22-30 September 2013. 


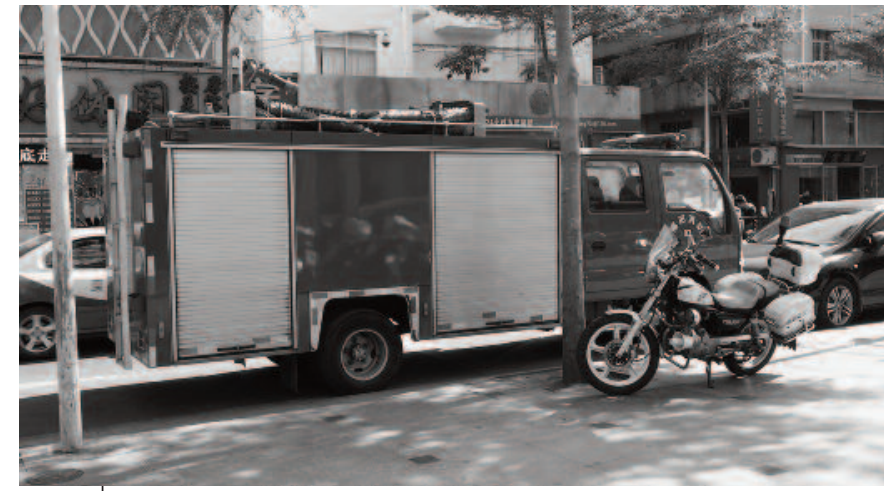

Photo 3 - Public security vehicles owned by the joint-stock companies.

(c) Edmund W. Cheng

Compared with settlements in the outskirts, the urban villages in the city centre tended to enjoy a better quality and quantity of public goods and services. Only the affluent urban villages could afford to provide recreational, communal, and cultural facilities. In Futian Village, an open-air cultural plaza the size of a football field was erected, and an underground car park large enough to hold hundreds of cars was constructed beneath it. In Caiwuwei Village, a total of 10 million yuan has been invested in education since 1992. The scholarship awards given to the descendants of native villagers to study at prestigious Chinese or overseas universities in 2012 totalled 625,000 yuan. In addition, according to the senior executives of the joint-stock companies, almost every village in the city centre has renovated or reinstalled their ancestor halls over the last decade. ${ }^{(45)}$

Nonetheless, a series of rationalisation projects have started to interfere with certain domains of the joint-stock companies in the areas of standardisation, cleanliness, and orderliness. Public goods related to health, education, and traffic have gradually been municipalised. Many native villagers and rural migrants complained about the city authority banning their clinics and primary schools and standardising their parking spaces and traffic signs in the urban villages. However, the municipal authority has not superseded the functions and authority of the joint-stock companies. These companies responded by negotiating the intervention boundaries with the state. Pharmacies and kindergartens remained intact, and schools and hospitals were built adjacent to the urban villages. Furthermore, these companies succeeded at maintaining control over the coercive force and becoming the service providers of rationalisation projects in the urban villages (Photo 3). ${ }^{(46)}$

The joint-stock companies have always shared the same office with their coercive force, resembling the classic "two units, same personnel" (yitao banzi, liangkuai paizi 一套班子两块牌子) structure. The coercive force was further divided into security guards (bao'an) and a collective security team (lianfang dadui). The former was responsible for managing ordinary public security such as organising daily patrols, issuing parking tickets, and collecting fines. The latter was deployed in times of emergency to combat organised crime and monitor large-scale demolitions. The funding of these two coercive groups came mainly from the management fees paid by tenants. The cost varied, ranging from 0.3 yuan per $\mathrm{m}^{2}$ per month in the outskirts to 1 yuan in the city proper. The standard size of the coercive force also varied, ranging from tens of people to several hundred. However, the regular personnel routinely underestimated the size and function of the coercive force. Over time, temporary personnel were employed to monitor large-scale demolitions and manage overt contestation in the urban villages or other villages. Revenue from

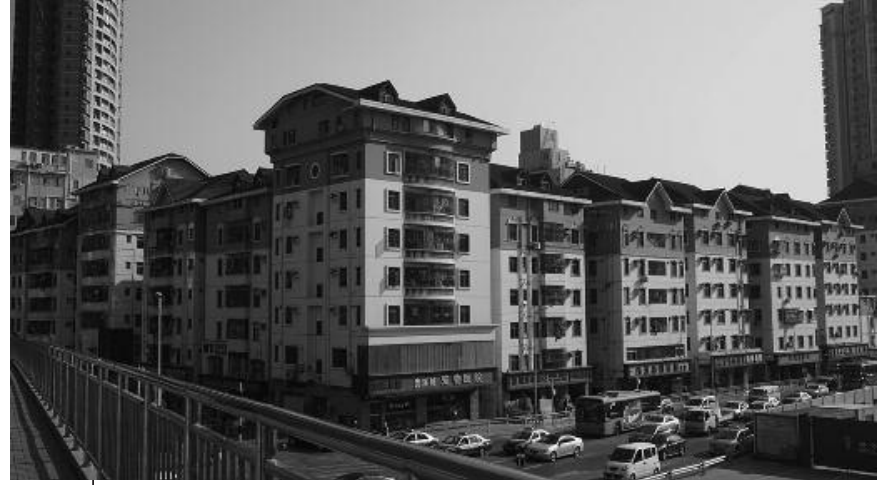

Photo 4 - Standardised building appearance. (c) Edmund W. Cheng

land sales and the rent of collectives was periodically drawn to finance this spontaneous yet persistent expense.

A deputy chairman of a joint-stock company in the Luohu District explained the incentives for regulating order and differentiating the treatment of native villagers and rural migrants as follows:

Nowadays the risky and nasty jobs will have to be handled by the temporarily employed security guards. Only migrants are capable of handling migrants, and only in this way could we fulfil the requirement of a harmonious society. Troublemakers must be taught a lesson. We cannot always count on external personnel (wairen) to protect this place. The villagers would not respect your authority if their requests for help were not properly addressed. How can we have the face to be greeted as chief and share a table with them in the ancestral hall? Chaos is not good for the renting business either. ${ }^{(47)}$

The authority and jurisdiction of the intermediate agencies have been recognised by external authorities. First, neighbourhood committees and district governments have continued to share budgets to manage the urban villages. Although the ratio has varied, the amounts were as large as 20 million yuan per year for the urban villages in the city centre after 2008. A budget was allocated to upgrade transportation and recreational facilities and improve the city's appearance. For example, in 2011, Luohu District spent 6.36 million yuan to conduct a water environment improvement project across several urban villages, most of which were billed to and managed by the joint-stock companies. ${ }^{(48)}$ Any rationalisation projects in the urban villages were thus channelled through the joint-stock companies.

Second, the coercive force of the state has observed the jurisdictions of the joint-stock companies. Prior to the 2011 Summer Universiade Games, the police and urban management enforcement (chengguan) guarded or blocked the entrances of tens of urban villages to control the massive amount of illegal construction and improve the city's appearance. This policy ultimately had little effect, as the landlords bypassed the checkpoints and smuggled the building materials in at midnight or dawn. A compromise was

45. Interviews, Shenzhen, 24 and 25 September 2013. See also Shenzhen Commercial Daily, 22 April 2012, A11;

46. SUVRO, Shenzhen Urban Village Redevelopment Annual Report 2006, op. cit;; interviews, Shenzhen, 13 August 2012.

47. Interview, Shenzhen, 24 September 2013

48. Interviews, Shenzhen, 24 and 25 September 2013; Shenzhen Municipality Luohu District Audit Report, 2013, No. 134, www.szlh.gov.cn/main/a/2013/i17/a244348_880658.shtml (accessed on 1 March 2014) 
reached when the respective companies promised to cap the further expansion of illegal structures at one or two storeys. The municipal apparatuses then fulfilled their improvement agenda by standardising the colours and rooftops of the buildings adjacent to the main avenues (Photo 4). ${ }^{(49)}$ The autonomy of the company was preserved despite carrying out the most comprehensive rationalisation project to date.

Because of the collective land ownership, the wellbeing of the landlords and tenants was tied to the general interests of the urban villages. A safe and governed enclave stabilised the rental value and monopolised the services in the villages, and also kept the interventions from city apparatuses in check. In this way, the role of joint-stock companies has not changed much compared with the pre-reform period. Indeed, these companies have continued to serve as producers and protectors.

\section{Exclusive stakeholders and fragile enclaves}

In contrast to the extensive and durable slum enclaves in the developing world, the development of China's urban villages has been sporadic and fragile. The differential treatment of farming, construction, and dwelling land has structurally determined the parameters of urban villages. Because the former two were requisitioned for urban development and the latter was retained for the construction of substandard accommodations, the rural land swallowed by urban sprawl has been cut into pieces. Although crowded in terms of density, urban villages built on land for dwelling were limited in space. Each of the original villages is randomly located, minute in scale, and often intersected by high-rises erected on former rural land.

These historical urban villages wind up looking rather fragile in light of the different stages of urban redevelopment. The Shenzhen government has increasingly treated urban planning as identical to the realisation of the exchange value of land in the market. ${ }^{(50)}$ Urban villages have thus become the main targets of elimination because they have been considered not only the roots of urban decay, but also a waste of land use value. In the midst of modern zoning, urban villages have been considered economically ineffective, aesthetically undesirable, and spatially incongruous.

As early as 1995, the Shenzhen government launched a land appropriation scheme to allocate new incentives for joint-stock companies to sell their remaining land for farming and construction and to reserve the land for dwelling. The joint-stock companies were offered a more favourable package once they agreed to sell a vast piece of land, supplemented by redevelopment rights and shares. The Central Business District of Luohu District, which included a number of the tallest buildings and largest shopping malls in South China, was acquired through this scheme. Joint-stock companies were turned into large landlords that owned and managed large commercial buildings and shopping malls in the area. Likewise, this scheme enabled the creation of the Civic Centre in Futian District, which served as the headquarters of the municipal government and its major servicing bureaus.

In 2005, a master plan for urban village redevelopment was published. This plan aimed to demolish as much as $8.9 \mathrm{~km}^{2}$ or around $10 \%$ of the urban villages in the municipality over five years. The prime project sought to redevelop Dachong Village in Nanshan District, which involved an area of $684,000 \mathrm{~m}^{2}$, the relocation of more than 70,000 households and a budget of 20 billion yuan. ${ }^{(51)}$ It adopted a state-corporative partnership in which the government consummated the acquisition and demolition and then auctioned the land off to giant developers, many of which belonged to different xitongs. In contrast, the redevelopment of Xiasha Village in Futian
District adopted a market-led model, in which the developers allocated shares to the joint-stock companies in exchange for the latter's land use rights and cooperation. The urban villages in the outskirts have been left behind thus far, mainly due to their relatively low exchange values. ${ }^{(52)}$

Whatever the model, it has required cooperation between the two groups of socialist land masters. Many xitongs have emerged as the largest developers in light of Shenzhen's economic boom. They have become socially networked and financially prepared for the huge redevelopment projects. They were frequently chosen as the developers under the government-led model and often approached by landlords in the market-led model. (53) One example is the Overseas China Town Group, a subsidiary under China's State-owned Assets Supervision and Administration Commission. In the inner city, this group built and managed the biggest electronic goods wholesale centre and the biggest theme park in South China. In the outskirts, it developed gated communities and villas for the urban middle class, all of which required a large parcel of land and hence the consent of the urban villages.

As the largest landowners of abundant or underdeveloped land, the jointstock companies have been pro-active and cooperative. When the companies were also the developers, they would make the offers directly. If not, they then coordinated sales and negotiated prices on behalf of the landlords. Although the law sets a minimum of $80 \%$ of the ownership in the redevelopment zone as a prerequisite for initiating a project, it did not deter or hinder the demolition of urban villages. ${ }^{(54)}$ The standard number of shareholders in a joint-stock company in Shenzhen has been kept at around 1,100. These shareholders have been prohibited from transferring their entitled shares of rural land, whose ownership belongs to the collective. Although a small number transferred their rights to other native villagers, the perimeter of the stakeholders ready for acquisition was limited.

Handsome compensation was another reason that accounted for the collective approval of urban redevelopment. Sometimes negotiations turned lengthy because of the booming real estate market, rather than because of organised resistance or violent conflict. For example, in redeveloping the aforementioned prime project, Dachong Village, the compensation price was set at 9,000 yuan per $\mathrm{m}^{2}$ in September 2006 and then rose to 12,000 yuan per $\mathrm{m}^{2}$ a year later. Eventually, one of the six-storey urban village buildings was sold for 12 million yuan in 2007, an average price roughly equal to 15,000 yuan per $\mathrm{m}^{2}$. This pattern has continued, thereby producing hundreds of millionaires overnight in the urban villages. ${ }^{(55)}$

Some landlords did resist redevelopment projects and turned their dwellings into "nail households" (dingzihu 钉子户), a term referring to the

49. Interview, Shenzhen, 13 August 2012; Fieldwork, Shenzhen, 22-30 September 2013.

50. You-tien Hsing, The Great Urban Transformation. Politics of Land and Property in China, Oxford, Oxford University Press, 2010, pp. 47-50.

51. Shenzhen Urban Planning, Land, and Resources Commission, Shenzhenshi chengzhongcun gaizao zongti guihua gangyao 2005-2010 (Shenzhen's Master Planning Outline for the Redevelopment of Urban Villages 2005-2010).

52. Futian District Urban Redevelopment Office, Futian chengshi gengin fazhan guihua gangyao (A Planning Outline for Urban Renewal and Development of Futian District), 12 October 2012; Luohu District Urban Redevelopment Office, Qu chongjianju gongzuo zongjie 2011 (Annual Work Summary of the District Redevelopment Office 2011),4 January 2012.

53. Chen Wending (ed), Weilai meiyou chengzhongcun (No Urban Villages in the Future), Beijing, China Development Press, 2011, p. 110.

54. Shenzhen Government, Shenzhenshi chengshi gengxin banfa shishi xize (Detailed Rule for Implementation of Shenzhen's Urban Redevelopment Regulations), Shenzhen Gazette, 2012, No.1.

55. "Tanfang Zhongguo zuigui dingzihu" (A visit to China's most expensive Nail Household), China Daily, 1 November 2012; "Liangge chengzhongcun gaizao xiangmu shushi yiwan fuhao dansheng" (The redevelopment program of two urban villages gives birth to tens of billionnaires), Southern Weekly, 4 February 2010; Chen Wending, No Urban Villages in the Future, op. cit., pp. 4-6. 
few residents who stayed at their properties and refused to be relocated. Although there was a mixture of personal, economic, and communal factors affecting their decision to resist, one political factor seems decisive. Records show that many dingzihu in Shenzhen's urban villages were either Hong Kong residents or foreign nationals. This unique status entitled them to the right to request assistance from state apparatuses such as the Overseas Chinese Affairs Office or the Hong Kong and Macau Affairs Office in the municipality, and gave them the leverage to approach the more critical local and foreign media. ${ }^{(56)}$ Although these dingzihu have routinely been depicted as victims of the coercive state or an inhumane planning regime, one must recognise that they were far from the most disadvantaged group. Their grievances were still propagated, and their negotiations supported by the authorities. Like the more obedient landlords, these dingzihu were also property owners who had access to various state apparatuses.

In contrast, the living space of rural migrants has been continuously reshaped, and their place in the most expensive area of the city centre was marginalised. Being neither property owners nor citizens deprived rural migrants of the right to receive compensation. In light of the redevelopment projects, most retreated to the urban villages in the outskirts, which continued to offer affordable accommodations for the time being. Others who had collective land ownership in the countryside floated back, contributing to the back-and-forth labour shortage in the coastal China area that has occurred since 2009. ${ }^{(57)}$ These two exit points have absorbed any organised resistance on behalf of the rural migrants, and as such have defined the fragility of the migrant enclaves in China's sunbelt.

Despite institutional absorption, rural migrants have continued to generate contestation through their residency and work in the city. In fact, urban living has increasingly become the vision and choice for the majority of second-generation rural migrants. This has resulted in part from their adherence to urban lifestyles and capitalist consumption, and in part from the fact that their collective land in the countryside has either been taken over by their parents or already expropriated by rural development and urban sprawl. The combined effect is that rural migrants are mentally prepared and economically tied to the urban system. As a forerunner in China's urban contestation, Shenzhen recognised that both the prospect of export-oriented growth and the transformation into a consumption-driven economy would draw heavily on manpower, skills, and savings of the rural migrants. To this end, a point-based system was introduced in 2010 to allow talented, educated, and long-serving rural migrants to obtain urban hukou. The system along with other experiments further revoked the hukou prerequisite for many public services, including subsidised housing and school places. In addition, many grassroots NGOs in Shenzhen have already made migrant assimilation their top priority. ${ }^{(58)}$ In other words, the future of China's megacities will depend on how rural migrants are incorporated into their social and urban fabrics rather than on how effectively the urban villages are torn down.

\section{Conclusion}

The spatial contestation in China's sunbelt city has largely been managed and regulated by the interplay between socialist institutions and neoliberal forces in the context of the rural-urban divide. Factory dormitories and urban villages, which have become the dominant forms of migrant accommodations in Shenzhen, are the physical evidence of their collaboration. The land appropriation mechanism has provided affordable and convenient ac- commodations to the most disadvantaged in a highly contested urban space. This enabled China to consume a cheap and reliable labour force for economic development and to check the social decay and ungoverned space that are common to third-world urbanisation.

These spatial arrangements have also revealed the mechanism by which power and wealth are distributed in China's heterogeneous migrant enclaves. Most rural migrants, despite residing in the city for years, have remained tenants who have neither owned a home nor constructed a community. Compared with the intermediate agencies, their rights and capacity have been marginalised over the course of urban sprawl and renewal. In this light, distance from the state apparatuses has continued to have a deterministic effect on one's well-being: the xitongs, joint-stock companies, and native villagers on one hand, and rural migrants on the other occupy opposing ends of a spectrum.

To be sure, the absence of overt resistance should not be mistaken for a lack of contestation. The rural migrants' continuous presence, including their residence, work, and exchange in Shenzhen, has transformed the socio-economic fabric of the city. However, its spatial and political order has largely been preserved by the intermediate agencies between collective land system and market force or between the state apparatuses and grassroots society. They provided affordable dwellings, distributed public goods, and mediated exit points, thereby regulating the migrant contestations and integrating the migrant enclaves into the formal city.

\section{Edmund W. Cheng is a PhD candidate at the London School of Economics and a lecturer in political science at the Open University of Hong Kong. \\ School of Arts and Social Sciences, Open University of Hong Kong, Homantin, Kowloon, Hong Kong (ewcheng@ouhk.edu.hk).}

56. Interviews, Shenzhen, 14 August 2012

57. Yunhan Shi, "Why Chinese Migrant Workers are Abandoning the Country's Top Cities," The Atlantic, 10 April 2013.

58. Lu Hua-xiang and Jiao Yi-xue, Jincheng wugong renyuan zhufang wenti diaocha yanjiu (Survey on the Accommodation Issues of Migrant Workers), Beijing, The Commercial Press, 2013, pp. 129131; Interview, Shenzhen, 12 March 2012. 